\title{
Um Capitão de quinze anos ou Angola na obra de Júlio Verne
}

\author{
Alberto Oliveira Pinto \\ Universidade de Lisboa
}

RESUMO: A LEITURA DA OBRA DE JÚLIO VERNE UM CAPITÃO DE QUINZE ANOS FLAGRA A PRESENCCA DE ANGOLA EM SUAS PÁGINAS E REFLETE COMO ALGUMAS DE SUAS IMAGENS REPERCUTEM EM OUTROS TEXTOS DE TEMPOS DIVERSOS.

ABSTRACT: THE READING OF THE WORK BY JÚLIO VERNE UM CAPITÃO DE QUINZE ANOS SHOWS THE PRESENCE OF ANGOLA ON ITS PAGES AND REFLECTS HOW SOME OF ITS IMAGES REVERBERATE ON OTHER TEXTS FROM SEVERAL TIMES.

PALAVRAS-CHAVE: LITERATURA E HISTÓRIA, JÚLIO VERNE, LITERATURA ANGOLANA KEY-WORDS: LITERATURE AND HISTORY, JÚLIO VERNE, ANGOLAN LITERATURE. 


\section{"viagem fatal" ao continente maldito}

O espaço africano subsahariano surge como pano de fundo em pelo menos seis romances de Júlio Verne (Nantes, 1828- Amiens, 1905), que constituem o corpus do ensaio de Carlos J. F. Jorge Jules Verne. O Espaço Africano nas Aventuras da Travessia: Cinq semaines en ballon (1863), Aventures de Trois Russes et de trois Anglais dans l'Afrique australe (1872), Un Capitaine de quinze ans (1872), L'Étoile du Sud (1884), Le village aérien (1901) e L'étonnante aventure de la Mission Barsac (1919) (JORGE, 2000). De todos, porém, o único que contempla especificamente o território angolano é Un Capitaine de quinze ans, razão pela qual o escolhemos para objecto deste estudo. Pretendemos, numa apreciação de Un Capitaine de quinze ans, publicado em França em dois volumes em 1872 e traduzido para português ainda no século XIX, mostrando Angola em plena época em que o tráfico de escravos subsiste apesar das medidas persecutórias preconizadas pela Grã-Bretanha, analisar algumas representações do imaginário de Júlio Verne, que mais tarde viriam a repercutir-se na literatura colonial portuguesa e na própria literatura angolana, acerca de realidades como o espaço geográfico angolano, os homens angolanos, os colonizadores portugueses e ainda o próprio tráfico de escravos e a escravatura.

A acção do romance desenrola-se entre o dia 2 de Fevereiro e o dia 25 de Agosto do ano de 1873 e é narrada em dois volumes, o primeiro dos quais se intitula $A$ Viagem Fatal e contém dezoito capítulos. $\mathrm{O}$ segundo, com um título bem apelativo para o leitor do exotismo oitocentista, $\mathrm{Na}$ Africa, é dividido por vinte capítulos.

O patacho "Pilgrim", pertencente ao armador norte-americano James W. Weldon, parte de Auckland, na Nova Zelândia, rumo a São Francisco, na costa ocidental dos EUA, percorrendo, portanto, o Oceano Pacífico de sudeste para noroeste. Leva a bordo, como passageira, a esposa do armador, Mrs. Weldon, acompanhada do seu filho Jack, criança de cinco anos, uma ama negra já idosa de nome Nan e ainda o primo Benedict, solteirão de cinquenta anos de temperamento pueril e excêntrico que se dedica maniacamente à entomologia, o estudo coleccionista dos hexápodes, insectos de seis patas. A tripulação do pequeno navio é constituída pelo capitão Hull, por cinco marinheiros e por um jovem praticante de quinze anos de idade chamado Dick Sand. Este é um enjeitado cujo nome próprio é o do homem que o recolheu, Richard, de que 
Dick é diminutivo, acrescido do apelido Sand, que em inglês significa "areia", em alusão à ponta de Sandy-Hook, a entrada do porto de Nova Iorque, lugar onde foi encontrado. A estes tripulantes acresce um oitavo elemento, o cozinheiro, o único homem a bordo que não é de origem americana, recém contratado em Auckland, indivíduo taciturno e enigmático cujo nome sinistro, Negoro, augura desde logo a perversidade que lhe será inerente ao longo de toda a trama do romance. Juntam-se-lhes ainda cinco negros recolhidos de um navio abalroado, todos cidadãos norte-americanos livres que regressavam ao seu país ao fim de três anos de trabalho rural ao serviço de um fazendeiro australiano. O mais velho, Tom, nascera e fora capturado algures em África não se diz nunca em que ponto exacto do continente - quando tinha seis anos e levado para a América como escravo, adquirindo já adulto a emancipação. Os outros quatro, Bat, filho de Tom, Agostinho, Acteão e Hércules, eram muito mais jovens e todos já nascidos na vigência da "lei do ventre livre". Hércules tem a particularidade de se vir a revelar, como o próprio nome indica, um bom gigante devotado e fiel, sobretudo em relação a Mrs. Weldon, ao pequeno Jack e a Dick Sand. Mas é recolhido igualmente um sexto sobrevivente do navio abalroado, um cão, corpulento mastim de nome Dingo que, segundo informação de Tom, fora pouco tempo antes encontrado nas margens do rio Zaire e em cuja coleira se encontram gravadas as letras $S$ e $V$, as iniciais do nome de um explorador francês, Samuel Vernon, desaparecido em África, provavelmente o seu antigo dono.

Tendo o capitão Hull e os seus cinco marinheiros sucumbido ao tentarem desesperadamente capturar uma baleia, Dick Sand, secundado por uma tripulação improvisada constituída pelos cinco negros, assume o comando do "Pilgrim", fazendo jus ao título do romance, e compromete-se a conduzir Mrs. Weldon e os restantes passageiros pelo menos até à costa ocidental da América do Sul. Mas os precoces conhecimentos científicos do capitão de quinze anos não são ainda suficientes para lhe permitirem detectar um acto fraudulento de Negoro. O sinistro cozinheiro de bordo consegue, às escondidas, aplicar um íman à agulha magnética da bússola do navio e desviar assim a sua rota. Ao fim de cinquenta dias, a 27 de Março, surpreendido por uma tempestade, o "Pilgrim" vai encalhar numa praia fronteira a uma floresta, onde os náufragos estabelecem acampamento por uma noite, durante a qual Negoro desaparece. Todos estão convencidos de que estão na América do Sul e essa ilusão vem a 
ser alimentada por Harris, um norte-americano que surge inexplicavelmente montado a cavalo, vindo da floresta, que lhes garante encontrarem-se no litoral da Bolívia e lhes propõe conduzi-los, subindo o curso de um riacho que desagua meio quilómetro a norte, a uma fazenda. Durante o percurso, Harris desaparece, e Dick Sand desconfia de que ele se encontra conluiado com Negoro.

Neste ponto da narrativa, que coincide com o último capítulo do primeiro volume, o herói compreende finalmente que se encontra no continente africano. Os indícios que o confirmam prendem-se por um lado com a natureza física, isto é, com a flora e a fauna, por outro com a natureza socializada, ou seja, com o tráfico de escravos e a escravatura. Entre os que dizem respeito à flora, evidencie-se, logo no momento em que os náufragos desembarcam, a presença junto à costa de adansónias, árvores conhecidas em Angola pelo nome de embondeiros ou imbondeiros (do kimbundu mbondo), inexistentes no continente americano (Ribas, 1998, p.93).

A fauna africana é identificada em três momentos cruciais do Capítulo XVII (pp.185-199), o penúltimo do primeiro volume, pelas personagens Jack, Dick Sand e primo Benedict. O pequeno Jack apercebe-se da ausência das araras coloridas e dos papagaios de penas verdes, abundantes nas florestas das Antilhas e da América do Sul, e na vez deles só vê os tipicamente africanos papagaios de penas cinzentas e cauda vermelha. Dick Sand está convencido de que avistou ao longe girafas a correr, não obstante Harris tentar enganá-lo assegurando-lhe que se trata de uma ilusão de óptica e que esses animais de pescoço comprido não são girafas e sim avestruzes, aves corredoras de que proliferam várias espécies igualmente no continente americano. Finalmente o primo Benedict captura um insecto que identifica como sendo a mosca tsétsé, propagadora da tripanossomíase, a doença do sono, que só existe na África Equatorial. Mais adiante, aliás, já no Capítulo V do segundo volume (pp. 58-67), o mesmo primo Benedict assegura que só em África se encontram exemplares do que designa por "sirafus", a variedade de térmites obreiras do formigueiro argiloso em cujo interior os náufragos se refugiam, que mais não é do que aquilo a que em Angola se chama um morro de salalé, isto é, um formigueiro de térmites cujo nome, salalé, provém do termo kimbundu sualala (Ribas, 1998, p. 264-265).

Quanto ao tráfico de escravos e à escravatura, é graças a uma chamada de atenção do velho Tom que Dick Sand identifica as manchas de sangue que vê 
nos troncos das árvores, assim como os restos de membros humanos mutilados, as cangas quebradas e as cadeias rebentadas que encontra no chão, como sendo vestígios recentes de caravanas (kibukas) de cativos acorrentados conduzidos pelos negreiros até ao litoral. O velho negro mal consegue balbuciar "Já vi... já vi... estes ferros... Era muito pequenino... Vi!...”, mas a Dick Sand, ainda que preocupado em ocultar a realidade a Mrs. Weldon e aos demais companheiros, logo ocorre exclamar horrorizado: "A África! A África Equatorial! A África dos negreiros e dos escravos!"’. O título do Capítulo XVIII, que se conclui com esta exclamação do herói, é precisamente "A palavra terrível".

\section{O espaço geográfico angolano}

Até aqui, nada evidencia Angola ou o seu território em relação à África em geral vista como o continente dos horrores - algo de similar ao que Joseph Conrad viria a imortalizar em 1904 com Hart of Darkness - e dos homens selvagens. Na perspectiva de Júlio Verne, que vai ao encontro da mentalidade ocidental da época, os africanos seriam, aliás, ainda mais selvagens ou, pelo menos, mais maus selvagens do que os americanos, pois Dick Sand, a fim de tranquilizar os companheiros, no momento em que enveredam pela floresta ainda convencidos de que se encontram na Bolívia, garante que "os índios americanos não se deviam confundir com os selvagens da África ou da Polinésia e que provavelmente as suas agressões não seriam de recear” (Verne, s.d., p.153). No seu cientismo rigoroso, Júlio Verne tem a preocupação de assinalar de passagem que, ao contrário do que sucederia se efectivamente Dick Sand e os seus companheiros se encontrassem no continente americano, não se avistam na costa nem palmeiras nem seringueiras, árvores que não são oriundas da África, se bem que umas e outras tenham sido plantadas e domesticadas em território angolano e fossem mesmo abundantes nesse ano de 1873. A palmeira terá entrado em Angola pelo menos logo após a descoberta do Brasil e a intensificação do tráfico atlântico de escravos. Quanto à seringueira ou árvore da borracha, igualmente trazida do Brasil, viria a proliferar em Angola na segunda metade do século XIX, mas não em regiões costeiras, a fim de que a borracha se transformasse numa mercadoria do comércio "lícito" em substituição do escravo (Henriques, 1997, p.515-563). 
Mas afinal em que ponto da costa de Angola é que os náufragos do "Pilgrim" desembarcaram? Segundo indicação dada já no segundo volume, o "Pilgrim" encalhou a cerca de cem milhas, ou seja, aproximadamente a 160 quilómetros, da foz do Kuanza (VERNE, s.d., p.88). Não se diz se a norte ou a sul, mas presumimos que a sul, uma vez que a norte, a essa distância da Barra do Kuanza, se encontra quer a cidade de Luanda - adiante, aliás, se dirá que Luanda dista 400 milhas de Kasonde (Verne, s.d., p.146) -, quer o litoral socializado dessa região. No entanto a descrição da paisagem feita por Júlio Verne, se exceptuarmos o exagero que atribui ao tom verdejante da vegetação, que em geral não se avista a não ser nas margens dos rios ou a um mínimo de 50 quilómetros para o interior, corresponde no essencial à de qualquer ponto da costa angolana, com a sua aridez sahélica e os seus barrocais a erguerem-se a partir das praias:

"Era uma estreita praia de areia, semeada de pedras escuras, da qual se erguia a rocha escarpada e cortada por sulcos irregulares. (...) No alto do rochedo (...) havia uma espessa floresta, cujos tufos de verdura, ondulantes à vista, se estendiam até às montanhas que formavam o fundo do quadro" (Verne, s.d., p.146).

Cremos tratar-se de uma praia situada algures entre Benguela-Velha, abandonada desde o século XVII e só vindo a ser recuperada em 1913, adquirindo então o nome de Porto Amboim, e o então Presídio de Novo Redondo (actual cidade do Sumbe), fundado em 1769 pelo governador Sousa Coutinho mais a sul, na foz do rio Ngunza (Milheiros, 1972, p.223-224 e p.230). O pequeno rio cuja embocadura Júlio Verne aponta a cerca de meio quilómetro (um quarto de milha) a norte do lugar do naufrágio é, certamente, o Longa. Estranhamos, no entanto, não haver qualquer referência aos vestígios da antiga povoação de Benguela-Velha, cuja existência Júlio Verne certamente ignorava. Do mesmo modo que as montanhas a que faz referência só podem ser as da Gabela e da Kibala, situadas na realidade muito mais para o interior. É aliás nesta direcção, ou seja, para nordeste, percorrendo mais de duzentos quilómetros do território do que em 1919 viria a ser designado por distrito e em 1975 por província do Kuanza Sul, que Dick Sand e os seus companheiros se dirigem, quer enquanto são guiados por Harris, quer já depois de capturados pelos negreiros uma vez saídos do formigueiro inundado. 
A partir deste ponto os seis negros, incluindo a ama Nan, são separados dos seus companheiros brancos e, mesmo sendo cidadãos americanos, destinamse a ser vendidos como escravos na costa, excepto Hércules, que logra fugir acompanhado do cão Dingo. Os negreiros não libertam os brancos Dick Sand, Mrs. Weldon, Jack e o primo Benedict, mantendo-os como reféns dos quais será exigido avultado resgate. São então todos conduzidos a "Um arraial nas margens do Cuanza" - é este o título do Capítulo VII do segundo volume -, arraial esse que provavelmente é o Dondo, a mesma localidade que mais adiante Júlio Verne referirá como sendo a terra natal do negreiro José António Alves. Tal como atrás Benguela-Velha se encontra ausente, também aqui é de estranhar que não se indique a existência, nem do Presídio de Cambambe, logo em frente ao Dondo, na margem sul do Kuanza, nem a histórica povoação de Massangano, no ponto de confluência entre o Kuanza e o Lukala, situada a menos de cinquenta quilómetros a noroeste do Dondo. A explicação reside no facto de Júlio Verne não ter tido acesso a nenhum autor português nem brasileiro sobre o território de Angola, nem aos cronistas dos séculos anteriores, como António de Oliveira de Cadornega, nem a Joaquim Rodrigues Graça, que percorrera o Kuanza trinta anos antes, em 1843, e muito menos aos exploradores científicos patrocinados pela Sociedade de Geografia de Lisboa, dos quais os primeiros a passarem por este rio serão Capelo e Ivens, na sua primeira viagem, que só ocorreria em 1877, aliás apenas dois anos depois de ter sido criada a entidade patrocinadora da expedição. As fontes do romancista restringiram-se aos testemunhos dos britânicos Livingstone, Standley e Cameron, sobretudo deste último, cujos percursos reproduz com grande entusiasmo em várias partes do romance.

As personagens de Júlio Verne, sempre conduzidas pelos negreiros, seguem do Dondo para o Kasonde, que a par do Kasanje e do Bié é evidenciado pelos referidos autores britânicos como sendo um dos mais prestigiados mercados angolanos de escravos. Júlio Verne utilizará rigorosamente, daqui em diante, quer no que diz respeito à paisagem e à localização do Kasonde, quer quanto a personagens verídicas que se entrecruzam com as fictícias, as descrições constantes do então recentíssimo relato Across Africa do tenente da marinha inglesa Verney Howet Cameron, que entre os anos de 1872 e 1876, à procura de Standley, o qual por sua vez tinha partido em busca de Livingstone e era dado como desaparecido - entretanto é o corpo do próprio Livingstone que 
a expedição de Cameron vem a encontrar pelo caminho -, atravessou o continente africano desde Zanzibar até S. Filipe de Benguela.

Kasonde, localidade que não encontrámos indicada em qualquer mapa ou índice toponímico de Angola (não se confunda com Kassongue, povoação localizada, precisamente, no Kuanza Sul) mas que Cameron descreve com pormenor, situa-se, segundo Júlio Verne, a cerca de 640 quilómetros (400 milhas) a sudeste de Luanda e a 480 quilómetros (300 milhas) a nordeste da foz do Kuanza, passando perto o rio Luhi (que também não deve confundir-se com o território do Lui, no Barotse, onde existia outro importante mercado que Silva Porto frequentou nas décadas de 1850 e 1860), afluente do Kuango, o qual, por sua vez, entroncará no Kongo/Zaire muito mais a norte, já fora de território angolano (Verne, s.d., p.88 e p.105-106). Faz parte, portanto, da actual província de Malanje, separada das Lundas pelo Luhi e pelo Kuango. À existência do seu mercado não é, decerto, alheia a saída dos portugueses da Feira de Kasanje, que se deu dez anos antes, em 1862, em virtude das revoltas do Jaga Bumba, nem a consequente criação do concelho de Malanje em 1867. Terá Cameron querido dizer Kisonde, nome de uma das onze divisões que integravam o concelho de Malanje em 1868 (Milheiros, 1972, p.193)? Ou, atendendo a que o prefixo ki é aumentativo e o prefixo ka diminutivo, ter-se-á Kisonde chamado Kasonde num tempo anterior em que, porventura, seria um povoado mais pequeno?

Numa fase final Hércules e Dick Sand logram salvar alguns dos companheiros, com os quais seguem numa canoa os cursos do Luhi e do Kuango, para norte, que lhes dá acesso ao Kongo/Zaire. A descida deste grande rio até ao Atlântico, interrompida a 183 quilómetros da foz pelas cataratas de Ielala não se referindo, evidentemente, as inscrições deixadas nas pedras por Diogo Cão e outros navegadores portugueses, que só viriam a ser descodificadas por Luciano Cordeiro já no início do século XX -, é descrita, já não a partir do relato de Cameron, e sim do de Standley.

\section{Os portugueses, o tráfico de escravos, o degredo e a personagem Negoro}

Analisar aqui a questão dos portugueses e do tráfico de escravos tem interesse sobretudo em relação às observações do tradutor português nas notas 
de rodapé. O tom de indignação nelas utilizado reflecte um dos argumentos mais obsessivos do discurso colonial português que viria a ser apropriado por uma grande parte da historiografia portuguesa posterior, influenciando igualmente intelectuais brasileiros e angolanos: o do tabu do tráfico de escravos e da escravatura, isto é, a operação retórica de negação ou de ocultação da longevidade da participação portuguesa nestas duas realidades e de atribuição a Portugal de um espúrio papel pioneiro na sua supressão, impostura que ainda hoje subsiste escandalosamente nos manuais escolares. A realidade, contudo, foi bem diferente, pois Portugal foi, não só o primeiro país europeu a desenvolver o tráfico da escravatura negra destinada à Europa e ao continente americano, como o último a aboli-lo juridicamente, assim como à própria escravatura, persistindo na sua prática clandestina até um período muito tardio do século XIX que atingiu em alguns casos os primeiros anos do século XX.

Impulsionado internacionalmente pela Grã-Bretanha em consequência da independência dos EUA e da revolução industrial de finais do século XVIII e consagrado no Congresso de Viena (1814-1815), o abolicionismo viria a ter a adesão quase imediata das legislações das potências europeias, como a Dinamarca (1792), a Grã-Bretanha (1806), a Suécia (1813), a Holanda (1814), a França (1815) e a Espanha (1817). Assente numa economia rural e esclavagista e numa sociedade secularmente desprovida de uma tradição filosófica e humanística, Portugal resistiria durante décadas a esta dinâmica. Graças à habilidade diplomática do duque de Palmela, o tráfico negreiro português conseguiu manter-se legal no hemisfério sul, entre a costa angolana e o litoral brasileiro, depois de independência do Brasil em 1822. O decreto emitido pelo marquês de Sá da Bandeira em 1836 proibindo o tráfico de escravos em todas as colónias portuguesas, sobretudo em Angola e em Moçambique, não seria aplicado por não ter tido a aceitação dos governadores dessas mesmas colónias, eles próprios envolvidos com o tráfico, e viria a ser revogado menos de um ano após a sua entrada em vigor. A aprovação em 1839 do bill de Palmerston pelo parlamento britânico permitiu aos navios ingleses fiscalizar os cargueiros portugueses a sul do Equador e declará-los piratas caso se descobrissem escravos a bordo, o que apressou a celebração de um tratado abolicionista entre Portugal e a Grã-Bretanha em 1842 que só viria a ser ratificado, isto é, a entrar em vigor entre as partes, cinco anos depois. Tal não obstou a que a Grã-Bretanha instalasse em São Tomé, Luanda e Lourenço Marques 
consulados cujo ponto estratégico da sua localização nestas cidades permitia aos ingleses vigiar o embarque de navios negreiros, o que viria a impulsionar sobremaneira o tráfico clandestino, que no caso de Angola não é feito apenas a partir dos arredores das cidades de Luanda e Benguela, mas igualmente de pontos recônditos do interior e da costa angolana e particularmente dos portos então independentes de Cabinda. O tráfico clandestino fora de Luanda e de Benguela viria a crescer ainda mais quando, depois de a legislação do senador brasileiro Euzébio Queiroz em 1850 proibir o desembarque de escravos em portos do Brasil, se assiste a um aumento considerável dos impostos alfandegários naquelas duas principais cidades angolanas. Se podemos apontar esta data como a da abolição legal do tráfico negreiro em Portugal e nas suas colónias, já a abolição da escravatura, prevista para 1878, será antecipada para 1876 por iniciativa de Andrade Corvo, ministro tão malquisto da sociedade portuguesa quanto o fora quarenta anos antes Sá da Bandeira. Mas insista-se que, no caso de Angola, só em Luanda e em Benguela é que as autoridades coloniais portuguesas se preocuparam a partir de então em punir os eventuais escravistas recalcitrantes, e mesmo assim sempre sob a pressão dos diplomatas britânicos e brasileiros (estes últimos a partir da década de 1860) e perante os desagrados manifestados pelos comerciantes angolanos. Noutros pontos do território, não obstante os esforços empreendidos por comerciantes como Silva Porto ou Rodrigues Graça por substituir gradualmente o escravo por outros produtos "lícitos" tais como o marfim, a cera e posteriormente a borracha (Santos, 1998, P.83-176), os negreiros actuaram com a maior liberdade durante a segunda metade do século XIX e frequentemente com a conivência dos governadores coloniais, apesar de algumas acções pontuais por parte destes - como foi o caso da tomada violenta do Ambriz em 1855 - destinadas a tentar convencer a Grã-Bretanha de que Portugal era um país abolicionista. O objectivo era, evidentemente, procurar demonstrar perante a comunidade internacional que Portugal tinha a ocupação efectiva da maioria dos territórios angolanos que reivindicava, princípio que só teria consagração jurídica na Conferência de Berlim (1884-1885), mas que então já se debatia entre as potências europeias como fundamento de ocupação do continente africano. $\mathrm{O}$ abolicionismo e a ocupação efectiva dos territórios vão, pois, andar de mãos dadas ao longo da segunda metade do século XIX e mesmo durante as primeiras décadas do século XX como princípios de direito internacional e é desesperadamente e 
sem convicção que os portugueses, ainda agarrados ao argumento obsoleto dos direitos históricos, procuram demonstrar aos seus parceiros coloniais que também os acatam (Pinto, 2006, p.213-219 e p.236-244).

As anotações de Pedro Guilherme dos Santos Dinis, tradutor de Um Capitão de Quinze anos de Júlio Verne, vão ao encontro desta argumentação. Perante a eloquente resenha de Verne acerca do tráfico de escravos e da escravatura, que ocupa todo o Capítulo I do segundo volume, e a observação acertada do romancista francês de que estas práticas só prevaleciam ao tempo nas colónias portuguesas, o tradutor não hesita em introduzir uma nota de rodapé tão extensa quanto o próprio capítulo, chegando a abranger três páginas (Verne, s.d., nota de rodapé das pp.13-15), onde começa desde logo por acusar Verne de se desviar, ainda que involuntariamente, da verdade e por declarar que, além de não haver qualquer facto que provasse a existência de escravatura nas "províncias ultramarinas" portuguesas, os portugueses se encontrariam ilibados de culpas quanto ao seu passado esclavagista pelo simples facto de não terem sido os únicos a escravizar africanos e a isso terem sido instigados pelos outros europeus e pelos muçulmanos. A estes argumentos farisaicos, infelizmente ainda hoje assaz utilizados na sociedade portuguesa, seguem-se outros que não menos o são, como a evocação das malogradas legislações de Sá da Bandeira e de Andrade Corvo e ainda do absurdo e persistente mito do decreto do rei D. José em 1773 proibindo o desembarque de escravos em Portugal continental e nas ilhas da Madeira e dos Açores, que faria do seu ministro Sebastião José de Carvalho e Melo (então já Marquês de Pombal), ao olhos néscios de uma certa intelectualidade lusa, um estranho percursor do abolicionismo em Portugal e até, pasme-se, na Europa! Não é necessário, evidentemente, conhecer a fundo a sociedade portuguesa do século XVIII para perceber que o referido decreto de D. José mais não foi do que uma medida circunstancial destinada a reduzir o número de indigentes, que o abandono dos escravos por parte de uma nobreza arruinada aumentava, e que o Marquês de Pombal, à semelhança de todos os portugueses do seu tempo, não só ignorava o que fosse o abolicionismo como, além de ter sempre possuído escravos, notabilizou-se mesmo como um grande incentivador do tráfico negreiro entre Angola e Brasil. Mais adiante, o tradutor persistirá nos seus propósitos supostamente patrióticos noutras anotações mais curtas, nomeadamente solidarizando-se com os que em Portugal protestaram contra as acusações de esclavagistas aos portugueses feitas por Cameron, que 
os considerava ainda mais cruéis do que os muçulmanos, e inclusive refutando peremptoriamente o tráfico clandestino (Verne, s.d., notas de rodapé da p.85 e da p.30). O facto de estas notas se dirigirem a um público juvenil torna o seu teor ainda mais grave e perverso, pois procuram ludibriar a juventude com a ideia subversiva de que basta que mudem as instituições numa sociedade para que as mentalidades e os interesses automaticamente se alterem.

A preocupação do tradutor em demonstrar os direitos históricos dos portugueses sobre os territórios angolano e moçambicano e mesmo sobre o espaço que medeia entre eles e que viria a dar corpo em 1886-1890 ao delirante sonho do Mapa Cor-de-Rosa encontra-se bem expressa na nota em que enuncia exaustivamente as travessias do continente africano anteriores a Livingstone, Grant, Speke, Burton, Cameron e Standley, como as dos brasileiros Lacerda e Almeida (1798-1799) e Joaquim Rodrigues Graça (1843-1847), as dos portugueses Monteiro e Gamito (1831-1832) e Silva Porto (1853-1856) e a dos angolanos Pedro João Baptista e Amaro José (1802-1811), às quais acrescenta as que se realizaram já depois da publicação de Um Capitão de Quinze Anos, como as de Capelo e Ivens, Serpa Pinto e Anchieta (Verne, s.d., nota de rodapé das pp. 32-33).

Merece ainda, a propósito do tradutor, uma apreciação da personagem Negoro. A sua nacionalidade foi deliberadamente omitida na tradução portuguesa por se tratar... de um português! Quem é Negoro? Júlio Verne dedica-lhe todo o Capítulo II do segundo volume, intitulado "Harris e Negoro". É através do diálogo entre os dois homens que se levanta todo o véu que pendia sobre o passado do cozinheiro português. E deparamos então com outra realidade que, a par do tráfico de escravos e da escravatura, a historiografia de Portugal ocultou: o degredo. Abolido apenas em 1932 e então substituído pelas colónias penais, o degredo de criminosos de delito comum esteve secularmente na origem de grande parte da população branca do Brasil, de Angola e de Moçambique. Inicialmente depositados nas fortalezas do litoral, como foi o caso da Fortaleza de S. Miguel em Luanda, os degredados portugueses eram depois postos em liberdade e acabavam na sua maioria por se tornar comerciantes, muitos percorrendo o sertão angolano como funantes (do kimbundu ku funa, comerciar) e obtendo dos povos do interior escravos destinados a embarcar na costa em troca de produtos como o vinho português ou a cachaça brasileira. Negoro foi, certamente, um desses homens, os verdadeiros povoadores das 
colónias, mas a quem os políticos portugueses da Primeira República, como Norton de Matos, e do Estado Novo, como Armindo Monteiro, não hesitaram em transformar em bodes espiatórios do tráfico negreiro e da escravatura, considerando-os a "escória da humanidade" e apodando-os de cafrealizados por viverem com mulheres negras. Ao seu enselvajamento procederia a literatura colonial de Henrique Galvão nos anos de 1930 (Pinto, 2002).

Antecipando-se a esta perspectiva, sem que aliás o tradutor português nada objecte em contrário, escreve Júlio Verne, a respeito dos negreiros, que "os agentes de origem europeia, em grande parte portugueses, são os facínoras que os seus respectivos países têm expulsado do seu seio, condenados, fugidos das prisões (...) Tal era Negoro (...)" (Verne, s.d., p.83). Tendo sido degredado para Angola depois de crimes praticados em Portugal, Negoro viveria durante anos do tráfico de escravos com toda a legitimidade e todo o apoio do governo colonial português. Em 1870, porém, num período em que as autoridades de Luanda e Benguela - e apenas estas - começam a perseguir os negreiros a instância dos britânicos e dos brasileiros, Negoro tem o azar de ser capturado quando conduzia uma caravana a um porto clandestino perto de Luanda, sendo encarcerado numa enxovia da capital de Angola. Daí consegue fugir e embarcar clandestinamente para a Nova Zelândia, de onde regressará dois anos depois como cozinheiro do "Pilgrim". O seu objectivo é retomar a actividade de comerciante de escravos, decerto a única que lhe permitiu em toda a sua vida ser um homem livre e próspero. Júlio Verne faz dele um vilão, raptor de Dick Sand e dos companheiros e assassino do explorador francês Samuel Vernon, e reserva-lhe uma morte hedionda e humilhante em combate com um cão, Dingo, com o qual se cruza no momento em que os heróis interrompem o périplo pelo Kongo/Zaire nas cataratas de Ielala.

\section{Os angolanos esclavagistas e enselvajados}

Se o tradutor se indigna, como vimos, com as acusações de esclavagismo feitas aos portugueses, em contrapartida é plenamente conivente com o retrato enselvajador que Júlio Verne faz dos africanos e que vai ao encontro dos estereótipos desenvolvidos pelos escritores portugueses já durante o século XX. Sempre partindo dos relatos de Cameron e com base em três figuras re- 
ais descritas pelo explorador inglês - José António Alves, Lourenço de Sousa Coimbra e o Moini Lunga -, Júlio Verne apresenta os angolanos segundo as categorias sociais em que o discurso colonial português os dividiria.

José António Alves, reputado comerciante de escravos entre Kasonde, Bié e Kasanje, é descrito como um negro de avançada idade que "de português tinha apenas o nome" (Sic.), pois na realidade chamar-se-ia Kendelé. Tendo em tempos trabalhado ao serviço de comerciantes brancos, há mais de vinte anos que traficava por conta própria (Verne, s.d., pp.107-108). À semelhança de Cameron, Júlio Verne diz que Alves nasceu no Dondo, embora segundo Capelo e Ivens fosse natural de Pungo Andongo, igualmente nas margens do Kuanza mas mais a leste. Num caso ou noutro, porém, não restam dúvidas de que se tratava de um ambaquista (aportuguesamento do kimbundu muku a mbaka, pl. aku a Mbaka, literalmente gente de Ambaca) de entre os muitos a quem o conhecimento da língua portuguesa e da escrita conferiu um estatuto superior ao dos kimbares, os guias das caravanas descendentes de escravos forros, o que lhes permitiu, nos séculos XVIII e XIX, dedicarem-se ao comércio no sertão angolano. Sendo embora na maioria negros e mestiços, consideravamse frequentemente "portugueses" ou descendentes de portugueses (Heintz, 2004, p. 59-61). Alves integrava-se, pois, na categoria que no século XIX se designava por "pretos calçados", intermediários dos europeus no comércio com as populações do interior, e que no século XX, em consequência da legislação iniciada em 1875 com o primeiro Código de Trabalho Indígena, desapareceria ou seria substituída pela dos "assimilados".

Lourenço de Sousa Coimbra, o braço direito de Alves, tem a particularidade de ser um mestiço (ou mulato), pois é neto de um português branco que, tendo emigrado para o Brasil, aí se casara com uma mulher negra ou mestiça com a qual fora para Angola e de quem tivera um filho, Júlio José Francisco Coimbra, também conhecido por Francisco José Coimbra, nascido na Caconda, major do exército português e capitão-mor do Bié entre 1838 e 1885, data em que foi substituído por Silva Porto (Milheiros, 1972, p.33 e Heintz, 2004, p.206). A descrição que Júlio Verne faz de Lourenço de Sousa Coimbra, um dos muitos filhos do major do Bié, mais não é do que a reprodução do retrato dele já traçado por Cameron, impregnado do preconceito do positivismo naturalista e poligenista que associa a ideia de degeneração da espécie dos mestiços à sordidez, à perversidade e à torpeza de carácter: "ente imundo quase nu, de 
olhar inflamado, guedelha áspera e encarapinhada, tez amarela, vestindo uma camisa esfarrapada e um saiote feito de ervas" (Verne, s.d., p.112).

Finalmente o Moini Lunga, soberano do Kasonde cujo nome é adequadamente alusivo aos títulos políticos dos mbundu orientais das margens do Kuango e do baixo Luhi - moini é uma corruptela de muene, o senhor das terras, e lunga é o símbolo dos espíritos das águas das chuvas, dos rios e dos lagos que, representado normalmente por uma figurinha humana em madeira, legitima a autoridade sobre as fronteiras territoriais (MILLER, 1995, p.59-63) -, personifica o africano enselvajado com todos os recursos usados pelo discurso colonial para negar a cultura ou a "civilização" do Outro, de que se destacam a animalização (associada, numa primeira fase, às feras e aos animais de carga, e numa fase mais recente ao antropóide), a antropofagia, o despotismo e a propensão excessiva para o sexo e para o abuso de bebidas alcoólicas ou de estupefacientes:

"Era o rei um velho precoce, gasto pelos vícios, queimado pelas bebidas espirituosas, maníaco, fazendo por mero capricho mutilar os seus súbditos, os seus oficiais ou os seus ministros, cortando a uns o nariz ou as orelhas, os pés ou as mãos a outros" (Verne, s.d., p.107).

O enselvajamento do africano destinou-se sempre a legitimar a dominação do homem europeu. No entanto, se entre o século XV e a primeira metade do século XIX essa dominação se processava pela submissão do africano à condição de escravo, a partir da segunda metade do século XIX, período em que às economias europeias interessa a abolição do tráfico de escravos e da escravatura e a sua substituição por uma exploração dos recursos naturais da África, o africano, que continua a ser visto como selvagem e atrasado, vai ser agora reduzido ao estatuto de indígena, destinado a fornecer mão-de-obra barata às unidades produtivas controladas pelos europeus. Assiste-se, consequentemente, a uma curiosa inversão do discurso colonial no sentido de transformar o esclavagismo num elemento de enselvajamento. Por outras palavras, se antes o mérito da escravatura residia em subtrair o africano à selvajaria, doravante o africano vai ser ironicamente considerado selvagem pelo facto de... ser esclavagista! Este discurso, também ele assaz utilizado pela literatura colonial portuguesa do século XX, é aqui introduzido por Júlio Verne ao fazer do Moini 
Lunga o principal cúmplice, enquanto fornecedor de escravos, do comerciante José António Alves, o qual por sua vez, sendo igualmente negro, "se entendia perfeitamente com o beberrão, a quem toda a província prestava vassalagem" (Sic.) (Verne, s.d., p.107).

À semelhança de muitos autores seus contemporâneos e de tantos que o seguiram, Júlio Verne faz do soberano africano um retrato físico escarnecedor, evidenciando os seus ornamentos, quer os tradicionais, quer aqueles que são introduzidos pelos europeus e que por isso se transformam em bens de prestígio entre os seus mas que segundo o discurso colonial não passam de demonstrações da ideia de que o colonizado jamais igualará o colonizador em grau de "civilização", não passando nunca de uma sua imitação ridícula e caricatural:

"Na cabeça trazia uma espécie de tiara ornada com garras de leopardo pintadas de encarnado e enfeitada com tufos de pêlo branco: era a coroa dos soberanos de Kasonde. Na cintura, dois saiotes de couro, bordados de pérolas, e mais enroscados que um avental de ferreiro. No peito, grande número de desenhos, sinal da antiga nobreza do rei, e os quais, dando-se-lhes fé, mostravam que a genealogia de Moini Lunga se perdia na noite dos tempos. Nos artelhos, nos pulsos e nos braços de Sua Majestade, braceletes de cobre, engastados de "sofis", e os pés metidos numas botas de lacaio com canhão amarelo, presente que the fizera Alves havia já vinte anos. Na mão direita uma grande bengala com castão de prata, na esquerda uma ventarola com o cabo enfeitado de missangas, no nariz a lente e os óculos do primo Benedict, que tinham sido encontrados na algibeira de Bat, e finalmente coberto por um velho chapéu de sol, tão cheio de remendos que parecia feito dos calções dos arlequins" (Verne, s.d., p.128).

Resta ainda referir que, a par do Mau Selvagem, hostil ao homem ocidental e personificado no Moini Lunga, também o Bom Selvagem, aquele que se mostra "grato" à acção civilizadora do homem branco e a ele se submete com docilidade enquanto amigo e aliado, se encontra presente neste romance de Júlio Verne, ainda que na figura de um norte-americano descendente de escravos, o bondoso e servil Hércules, que mais do que uma criança grande - o mérito do colonizador, segundo o discurso colonial, reside sempre na transformação dos "déspotas" em "crianças grandes" -, é uma criança gigantesca ou, como o 
próprio nome indica, hercúlea. O Capítulo XVI do segundo volume, intitulado "Um Meganga" e onde se descreve a aventura de Hércules, sob o disfarce de um meganga (ou nganga, o sacerdote curandeiro da tradição bantu), subtraindo Mrs. Weldon e o pequeno Jack à antropofagia do povo do Moini Lunga, é disso um bom exemplo.

\section{Referências bibliográficas:}

Bibliografia Activa

VERNE, Júlio. Um Herói de Quinze Anos'. Primeira Parte. A Viagem Fatal, Trad. Pedro Guilherme dos Santos Dinis, Capa de José Cândido e Desenhos da edição original francesa de 1872 de Henri Meyer, gravados por Ch. Barbant. Lisboa: Livraria Bertrand, s.d., 210 p.

VERNE, Júlio. Um Herói de Quinze Anos. Segunda Parte. Na África, Trad. Pedro Guilherme dos Santos Dinis, Capa de José Cândido e Desenhos da edição original francesa de 1872 de Henri Meyer, gravados por Ch. Barbant. Lisboa: Livraria Bertrand, s.d., 226 páginas.

\section{Bibliografia Passiva}

HEINTZE, Beatrix. Pioneiros Africanos. Caravanas de carregadores na África Centro-Ocidental (entre 1850-1890). Trad. Marina Santos. Lisboa: Caminho, 2004.

HENRIQUES, Isabel Castro. Percursos da modernidade em Angola. Dinâmicas comerciais e transformacões no século XIX. Lisboa: Instituto de Investigação Científica Tropical, 1997.

HENRIQUES, Isabel Castro. Os pilares da diferença. Relações Portugal-África séculos XVXX. Lisboa: Centro de História da Universidade de Lisboa, 2004.

JORGE, Carlos J. F. Jules Verne. O espaço africano nas aventuras da travessia. Prefácio de Helena Carvalhão Buescu. Lisboa: Edições Cosmos, 2000.

1 Título da edição original francesa de 1872: Un Capitaine de Quinze Ans. 
MILHEIROS, Mário. Índice Histórico-corográfico de Angola. Luanda: Instituto de Investigação Científica de Angola, 1972.

MILLER, Joseph C. Poder Politico e Parentesco; Os Antigos Estados Mbundu em Angola, Trad. Maria da Conceição Neto (ed. original da Oxford University Press de 1976). Luanda: Arquivo Histórico Nacional, 1995.

PINTO, Alberto Oliveira. Cabinda e as construções da sua história. 1783-1887. Lisboa: Dinalivro, 2006.

PINTO, Alberto Oliveira. O concurso de literatura colonial da Agência Geral das Colónias (1926-1951); Colonialismo e Propaganda. In Clio. Lisboa: Centro de História da Faculdade de Letras da Universidade de Lisboa, Nova Série, Vol. 7, 2002, p.191-256.

RIBAS, Óscar. Dicionário de regionalismos angolanos. Matosinhos: Contemporânea Editora, 1998.

SAID, Edward W. Culture et Impérialisme. Trad. Paul Chemla. Paris: Fayard Le Monde Diplomatique, 2000.

SANTOS, Maria Emília Madeira. Nos caminhos de Africa. Serventia e posse. Angola Século XIX. Lisboa: Instituto de Investigação Científica e Tropical, 1998.

SERRÃO, Joel (Dir. de). Dicionário de história de Portugal, 6 Volumes. Porto: Livraria Figueirinhas, s/d (1981).

SPURR, David. The Rhetoric of Empire. Colonial Discurse in Journalism, Travel Writing and Imperial Administration. Durban \& London: Duke University Press, 1993. 